\title{
Me, Myself, And You? National Self Interest, Global Social Concern, And The Role Of The WTO In International Trade Policy
}

Lynda D. Vargha, (E-mail: lvargha@skidmore.edu), Skidmore College

\begin{abstract}
This paper presents a teaching method that meshes the theoretical foundation of the prisoner's dilemma with a student centered problem-solving approach to address the roles of national selfinterest and global social concern in the making of trade policy through the WTO. The in-class activities introduce the student to the underlying incentive structure of the prisoner's dilemma and require each student to weigh self-interest and group well-being in his/her decision-making process as a member nation of the WTO. Through these exercises, students discover the importance of international agreements and the need for a binding set of rules and enforcement mechanisms governing global trade. In addition, these activities are an effective springboard for a discussion of national sovereignty and the expanding role of the WTO.
\end{abstract}

\section{Introduction}

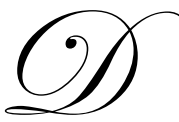

uring the lifetime of most of today's undergraduate students, the world has seen the increased integration of global economic and political systems. In recent years, globalization has lead undergraduate institutions to expand curricula to encompass international issues. Similarly, student activism outside of the classroom has become more centered on international policy and the organizations that administer international agreements. Noticeable student involvement has ranged from campus demonstrations and "teach-ins" on international human rights, environmental policy and trade policy to participation in some of the most violent protest at the November 1999 Inter-Ministerial Meeting of the World Trade Organization (WTO) in Seattle.

Central to student opposition to the WTO is the concern that it is used as an avenue for already powerful nations (and their corporations) to selfishly pursue their own economic and political goals with little consideration for the impact on poorer countries, workers, or the environment. ${ }^{1}$ Given this student discontent, how can college professors best use the classroom to teach undergraduate students about the roles of national self-interest and global concern in the making of the global public policy?

This paper presents a teaching method that meshes the theoretical foundation of the prisoner's dilemma with a student centered problem-solving approach that addresses the roles of national self-interest and global social concern in the making of trade policy through the WTO. The in-class activities introduce the student to the underlying incentive structure of the prisoner's dilemma and require each student to weigh self-interest and global well-being in his/her decision-making process as a member nation of the WTO. Through these exercises, students discover the importance of international agreements and the need for a binding set of rules and enforcement mechanisms governing global trade. In addition, these activities are an effective springboard for a discussion of national sovereignty and the expanding role of the WTO into areas such as international competition policy, environmental policy, and labor standards. 


\section{Literature Review}

Game theory studies the strategic interactions of agents (individuals, firms, countries, etc.) in situations where each agent has an effect on the outcome but cannot completely control it. The prisoner's dilemma dates back to 1950 and is one of the most common games studied. The game provides a striking result. If each agent acts in his/her self-interest, each will be worse off than if he/she had cooperated with the other.

This result makes the prisoner's dilemma an excellent theoretical framework in which to study the tension between self-interest and social responsibility in both individual and group decisions. For example, political scientists have used the prisoner's dilemma to examine issues from diplomacy surrounding the arm's build-up to Hobbes' vision of government (Gowda, 1996). Social psychologists have used the prisoner's dilemma to understand individual and group behavior in situations such as crowd panic (Gleitman, 1987) and labor negotiations (Worchel and Cooper, 1983). In addition, the basic dilemma is applicable to a wide range of economic issues including common resource problems, collusive behavior by firms and corporate advertising strategy (Mankiw, 2001).

Since the prisoner's dilemma is such an effective teaching tool, instructors have focused on teaching methods centered on student decision-making activities. Bodo (2002) created a computer program that simulated a repeated prisoner's dilemma game. Using the program in a tournament setting, he required students to create and update their own strategies for playing with each round of the game. Equally effective, Holt and Copra (2000) used a simple game using playing cards to simulate a prisoner's dilemma game to motivate discussion of a variety of economic applications. These authors found that such interactive classroom activities stimulated student discussion and increased student understanding of strategies.

\section{Theoretical Framework: The Prisoner's Dilema}

The original prisoner's dilemma story involves two criminals being detained by the police in different rooms so that they are unable to confer with each other. ${ }^{2}$ In order to teach the basic theoretical framework, the instructor should choose two students to send out of the room one at a time, and present the following dilemma to the remaining student and the entire class.

"The two of you have committed a crime. The police have you locked up in separate rooms, so you will not have an opportunity to communicate with each other. You will each be offered the same deal."

Write the following deal on the board.

- If both confess to the crime, each will receive a sentence of 10 years in prison.

- If neither confesses to the crime, each will be convicted of a lesser charge and will receive a sentence of 1 year.

- If one confesses and the other does not, the confessor will be given immunity from prosecution in exchange for his/her testimony and will go free. The individual that does not confess will receive the full sentence of 25 years on prison.

The normal form of the game is illustrated in Figure 1. In this game, if each player acts in his/her selfinterest, the Nash equilibrium (confess, confess) will be reached. The actual strategy played and outcome reached depends on the individual's propensity to act in a self-interested manner.

The activity works best if the instructor chooses two individuals who are known to be friends as it makes the struggle between doing what is best for one-self and what is best for the group more apparent. While there were instances where both students easily came to the decision to keep quiet, most students struggled with the conflict between self-interest and a sense of responsibility to the other person. The struggle was apparent in comments made jokingly like "Will I see her afterwards?" or "I had better not confess or he will give it to me." Often, a student tried to guess which action his/her partner would take thinking that it was ok to act in his/her own self-interest if that was 
what his/her partner was likely to do. This activity yielded a variety of results from both confessing to one student "ratting out" another.

Regardless of the actual outcome, the classroom exercise effectively illustrated the underlying incentive structure of the game to the students. If both individuals unilaterally acted in their self-interest, the outcome would have been worse for each than if they had felt some responsibility for the welfare of the other individual. When the two participants were close friends, they generally did not confess and received the outcome of only one year in jail for each. Thus, considering the well-being of the other individual rewarded both players. Even if the two students were not friends, they immediately recognized the fact that they could have made an agreement beforehand to not confess to the crime and avoid the Nash equilibrium. Therefore, even if individuals did not feel a great sense of social responsibility, they did realize that all could be make better off by a binding agreement. ${ }^{3}$ This was an important conclusion for students to carry into the next activity.

\section{The Case Of The WTO}

After experiencing the basic prisoner's dilemma, students possessed a general understanding of the incentives underlying the game and were able to apply them to real world applications. The example used in this section illustrates the purpose of international trade agreements and the organizations (such as the WTO) that administer and enforce these agreements.

This student-centered problem-solving activity begins by seating students in a circle and presenting them with the following problem:

"You each represent a different country that relies on international trade in goods and services with the other countries represented here. You must choose one of two policies: impose a protective tariff on foreign goods being imported into your country, or pursue a zero tariff free trade policy. Each of your trading partners faces the same decision." 4

Write the following on the board:

- If a country and its trading partner both choose protectionism, trade flows (and their benefits) will be reduced. Foreign markets will be closed to exports and domestic consumers will pay more for imported goods than under free trade. ${ }^{5}$

- If country and its trading partner choose free trade, both will gain from open foreign markets for their exports and less expensive imports

- If one country chooses free trade and the other chooses protectionism, the protected country will gain by being able to export goods to an open foreign market while protecting its own industry from foreign competition. The country choosing free trade will lose since it now faces closed markets for its exports and increased competition in domestic markets from imports.

The outcomes can be quantified and the level of global well-being can be represented in the following normal form game. The gains and losses can be quantified in the normal form game matrix to ease the analysis of the game. As with the original prisoner's dilemma game in Figure \#1, the actual quantity of each payoff can be arbitrary as long as the payoffs reflect the underlying incentive structure of the game. That is, the total welfare (U.S. + trading partner) for cooperative free trade must exceed that the welfare for a trade war. In addition, unilateral defection from the free trade agreement must increase the payoff to the defector while lowering that of the country sticking with free trade.

The payoff matrix illustrates that cooperative liberalization has the same incentive structure as the prisoner's dilemma. While each country would be better off if both set zero tariffs, each has an incentive to deviate from the liberalization agreement. For example, suppose that countries have agreed to cooperatively lower tariffs. In doing so, the consumers of each country pay less for imported goods while export industry benefits from more open markets abroad for their exports. ${ }^{6}$ However, there is an incentive for each country to unilaterally deviate from 
the liberalization agreement. If the U.S. were to raise tariffs, while its trading partner kept tariffs low, the U.S. would be better off than if it adhered to the liberalization agreement as it still enjoys open markets for its exports, but is able to restrict import competition for its import competing industry. Cheating by the U.S. would make its trading partner worse off than if both had stuck to the liberalization agreement as it is now faced with a less open market for its exports and more import competition for its domestically produced goods. Given that the U.S. has cheated on the liberalization agreement, the trading partner is now better off raising its tariffs as well, which results in a trade war or an end to free trade, making both countries worse off than if they had honored the agreement. Therefore, imposing a tariff is the dominant strategy and the trade war is the Nash equilibrium.

In this activity, students made decisions as a group of trading partners. Each student (representing a country) was required to commit to a unilateral decision before revealing his or her decision to others in the class. ${ }^{7}$ In the first iteration of the game, students were not allowed to discuss their decisions and revealed their decisions at the end of each round. Multiple rounds were played, and students were not allowed to speak to one another about the decision process. In almost every case, a trade war resulted. Unable to come to cooperative agreements, most students made self-interested decisions and imposed tariffs. Even when the game began with most nations pursuing free trade and only a few setting tariffs, after a few rounds everyone realized that free trade would not be achieved and other nations imposed protection in retaliation.

In the second iteration of the game, students were allowed to speak with one another before each round. In most cases, one or two students took a leadership role and attempted to convince to group to agree to pursue free trade. Theoretically, it was possible for all students (countries) to agree to free trade in the first round, but often one or two students chose to impose tariffs, despite the wishes of the majority. This defection was often met with one of two responses: a movement toward free trade or a movement toward a trade war. Students achieved free trade when the individuals committed to the free trade agreement were successful at swaying the defectors' decisions through peer pressure or threats to impose tariffs in retaliation. On the other hand, a trade war resulted when the original defectors were not persuaded to go along with the group, and other students abandoned the free trade agreement and imposed tariffs in retaliation.

The difficulty in achieving liberalization without a binding agreement or enforcement structure is due to the fact that the decision to impose tariffs is a unilateral one, and there is an individual incentive to cheat on the agreement. When additional rounds were played, students eventually attempted to frame a binding agreement that addressed the individual incentive to cheat on the liberalization agreement. Students found that the most effective means of enforcement was a punishment strategy aimed at the defecting nation. In some cases only one or two students played the role of enforcer and imposed retaliatory tariffs, but in other cases, all countries agreed to impose tariffs against the defecting nation, increasing the level of punishment and decreasing the likelihood of one nation defecting from the agreement.

The fact that students inevitably attempted to impose rules on those setting tariffs made the need for a binding agreement clear. This activity illustrated the need for multilateral trade agreements and for enforcement mechanisms that address underlying incentives. In the case of international trade, the WTO administers the trade agreements of its member nations thus providing this binding agreement. ${ }^{8}$ The WTO provides a framework of rules, enforcement mechanisms and dispute settlement procedures under which member nations trade. In addition, the expanding role of the WTO has come under fire in recent years, and this activity provides a good springboard for a discussion of global well-being and national sovereignty over issues such as international competition policy, environmental policy, and labor standards.

Reading materials and discussion questions for an expanded discussion of the role of the WTO are provided in the Appendix.

\section{Results}

While the above activities are applicable to courses in a variety of disciplines, the author has used them in all levels of economics classes from Introduction to Microeconomics to a seminar on the Economics of 
Globalization. With few exceptions, students had not seen the prisoner's dilemma before, and became engaged in the interactive way in which it was presented in class. After the first prisoner's dilemma exercise, they were able to identify the incentive structure underlying the game. With this foundation, the extension to the multilateral liberalization example followed easily. Students were drawn in by the use of a real life policy question, and the foundation of the prisoner's dilemma enabled them to come to a better understanding of the underlying individual incentive structure that international agreements must address.

As important as the theoretical framework was to achieving this outcome, the interactive, problem-based teaching method also contributed to student understanding. Before adopting the methodology discussed in this paper, the prisoner's dilemma and multilateral liberalization examples were presented in a lecture format without the use of student-centered problem solving activities. Once interactive teaching methods and materials were used, students exhibited a better depth of understanding as expressed in class discussions and on exams. For example, when asked to evaluate a hypothetical trade dispute between two countries on an exam, students were able to explain the underlying tension between national self-interest and global responsibility, provide possible policy recommendations, and evaluate the pros and cons of different policy options. The emphasis on policy also allowed students to examine issues of interest to them and to bring their own outside knowledge of political and economic issues into the classroom.

\section{Conclusions}

This paper presented classroom activities that use the prisoner's dilemma to effectively examine the roles of national self-interest and global well-being in international policy decisions. The theoretical foundation of the prisoner's dilemma, along with interactive teaching methods and relevant policy materials, bridges the theory that college students learn in the classroom with the real world social and political issues that interest them. Students reacted favorably to the emphasis on problem solving, the use of real life policy issues and to the interactive style in which these issues were presented. Not only were students more actively engaged in classroom activities than they were in lecture format presentations, they also displayed that they were better able to explain underlying tension between individual self-interest and social responsibility, provide possible policy recommendations, and evaluate a variety of policy options.

Moreover, it is striking that the concept of global responsibility is alive and well and living in the college classroom. Even in economics and business courses, where self-interest plays an important role in guiding the invisible hand of the economy, students possess a tremendous awareness of the shortcomings of self-interest and the need to enact international public policy that addresses the incentives of individual nations. In short, students recognize that in a global economy, it is the role of international economic and political agreements to temper national interests with a sense of global responsibility.

\section{References}

1. Bodo, P. (2002). In-class Simulations of the Iterated Prisoner's Dilemma Game. Journal of Economic Education, 33 (3), 207-216.

2. Clark, J (2003), Worlds Apart: Civil Society and the Battle for Ethical Globalization, Kumarian Press: Bloomfield.

3. Gleitman, H. (1987). Basic Psychology. New York: Norton.

4. Gowda, M.V. Rajeev (1996). Teaching the Prisoner's Dilemma. Journal of Policy Analysis and Management, 15 (4), 646-653.

5. Holt, C.A., \& Capra, M. (2000). Classroom Games: A Prisoner's Dilemma. Journal of Economic Education, 31 (3), 222-236.

6. Mankiw, N. G. (2001). Principles of Microeconomics. Harcourt.

7. Worchel, S., \& Cooper, J. (1983). Understanding Social Psychology. Homewood, IL: Dorsey. 
Figure 1: The Prisoner's Dilemma Criminal A

Confess

Don't Confess

Confess

Criminal B

Don't Confess

\begin{tabular}{|l|l|}
\hline & \\
A: 10 years & A: 25 years \\
B: 10 years & Go Free \\
\hline & \\
A: Go Free & A: 1 year \\
B: 25 years & B: 1 year \\
\hline
\end{tabular}

Figure 2: Multilateral Liberalization USA

Tariff

Free Trade

Tariff

Trading

Partner (TP)

Free Trade

\begin{tabular}{|l|l|}
\hline & \\
USA: $\$ 500$ Billion & USA: $\$ 300$ Billion \\
TP: $\$ 500$ Billion & 900 Billion \\
\hline USA: $\$ 900$ Billion & USA: $\$ 800$ Billion \\
TP: $\$ 300$ Billion & TP: $\$ 800$ Billion \\
& \\
\hline
\end{tabular}

Appendix

The Case Of The WTO Discussion Questions And Resources

Discussion Questions

- In the absence of any international agreements regarding the imposition of import tariffs, what is the likely outcome?

- What would be the outcome if each country acted with the best interests of all countries in mind?

- What international agreements are in place to deter a trade war? What restrictions do they place on participating countries?

- How well are these agreements enforced?

- What privileges does a nation receive as a member of the WTO?

- What is the role of the WTO in enforcing trade agreements of member nations?

- Go to the WTO web site (www.wto.org) and find a recent case in which the WTO ruled on a trade dispute. Which countries were involved in the dispute? What was the nature of the dispute and how was it resolved?

Resources

The World Trade Organization web site (www.WTO.org) provides excellent background information and history about the GATT and WTO. There is also information on specific trade rules and dispute settlement cases. Public Citizen (www.citizen.org/) was founded by Ralph Nader and is a good resource for articles critical of the expanding role of the WTO. Pairing an article from this source with one from the WTO or U.S. Trade Representative web site (www.ustr.gov/wto/) is a good way to stimulate discussion about the role of the WTO that extends beyond the basic exercise. 


\section{Endnotes}

$1 \quad$ See Clark 2003.

2 There are many variations on the story of the prisoner's dilemma. While the crime and possible sentences may vary slightly in each version, the basic incentive structure underlying the dilemma remains the same.

3 If a player is concerned about the well being of the other player (or makes a binding agreement with the other player), neither will play the dominant strategy of "confess," and the Nash equilibrium outcome will be prevented. Instead, both will keep quiet and the welfare of the group will be maximized (only one year of prison for each).

4 A tariff is an import tax that results in an increase in the domestic price of a good and a decrease in the quantity of the good entering the country.

5 As its name suggests, protectionism does protect domestic import competing industry from foreign competition. Lowering a tariff will hurt the domestic producer of a good, but economists find that the gains from the lowered price for consumers and more open markets from trading partners outweigh this loss. Therefore, while there are winners and losers from trade liberalization, economists argue that the gains from trade outweigh the losses.

U.S. tariff on a foreign import will increase the price that American consumers must pay for the good and limit the quantity of foreign imports entering the U.S. A foreign tariff on a U.S. manufactured product will result in a higher price for foreign consumers and a decrease in the quantity of goods exported from the U.S. into foreign markets. It follows that, on the whole, both countries will gain if both simultaneously lowered their own import tariff, resulting lower prices of imported goods and larger export markets for both countries. As a result, cooperative liberalization provides both countries with a greater level of welfare than mutually high tariff levels.

This can be done by having each student write the decision to impose tariffs or to pursue free trade on a card. The instructor could also give each student one red card and one black card and have him/her choose black for tariff or red for free trade.

8 The WTO was established in 1995 as a result of the Uruguay round of negotiations of the General Agreement on Tariffs and Trade (GATT). The GATT was formed in 1945 with member nations focusing on cooperative tariff reduction. In recent years, especially with the establishment of the WTO, the organization has turned its focus to the reduction of non-tariff barriers, trade in services, competition policy environmental policy etc. WTO agreements are negotiated by member nations and signed by the legislative body of each nation. Unlike GATT, since its establishment, WTO has been the focus of protest, especially among student groups. 
Notes 